\title{
EFEKTIVITAS METODE AERASI DALAM MENURUNKAN \\ KADAR BIOCHEMICAL OXYGEN DEMAND (BOD) AIR LIMBAH LAUNDRY
}

\author{
Ida Ayu Putu Candra Pramyani ${ }^{1}$, Ni Made Marwati ${ }^{2}$
}

\begin{abstract}
Laundry services continue to increase along with the increase in community activities. The growth of laundry services has an impact on increasing the amount of detergent usage and laundry waste. One of the wastewater treatment is by aeration. The purpose of this study is to determine the effectiveness of aeration methods in reducing Biochemical Oxygen Demand (BOD) Oliv Laundry Jaya wastewater. This type of research is quasiexperimental. This research was conducted by conducting aeration on laundry wastewater with a time difference of 30 minutes, 60 minutes and 90 minutes for a sample of 1 liter and an air transfer rate of 5 liters / minute. This research was carried out with six replications. The ability of the aeration method in decreasing BOD of laundry wastewater was tested with ANOVA with sig 0, 000 shows that there is a difference in the effectiveness of decreasing BOD laundry wastewater with aeration treatment of 30 minutes, 60 minutes and 90 minutes. The conclusion of this research shows that aeration of wastewater for 90 minutes is the most effective contact time to reduce BOD of wastewater laundry.
\end{abstract}

Keywords: Aeration, BOD, Air Transfer

\section{PENDAHULUAN}

Biochemical Oxygen Demand (BOD) adalah jumlah oksigen yang dibutuhkan oleh bakteri dalam melakukan proses dekomposisi aerobic terhadap bahan organic dari suatu larutan. Nilai BOD menyatakan jumlah oksigen, tetapi untuk mudahnya dapat juga diartikan sebagai gambaran jumlah bahan organik mudah urai (biodegradable organics) yang ada di perairan. Air sisa kegiatan atau air limbah dapat berasal dari berbagai usaha, salah satu kegiatan yang menghasilkan air limbah dengan BOD tinggi yaitu pada usaha laundry. Hal tersebut sesuai dengan studi yang dilakukan oleh Hermaning (2016) bahwa kadar BOD air limbah laundry mencapai angka 260,3 mg / L. Dalam proses pembuangan limbah laundry, saat ini hampir semua usaha laundry membuang limbah langsung ke badan air ataupun di resapkan ke tanah. Pembuangan limbah laundry tanpa mengalami proses pengolahan 
terlebih dahulu dapat meningkatkan pencemaran terhadap badan air dan lingkungan tempat pembuangan limbah tersebut (1). Dalam kegiatannya jasa laundry memanfaatkan penggunaan detergen sebagai bahan baku dalam kegiatan usaha, dikarenakan dinilai efektif sebagai pembersih jika dibandingkan dengan sabun biasa (2). Detergen merupakan suatu produk penyempurnaan dari sabun yang dapat mengatasi kesadahan air dan larutan asam. Detergen terbuat dari bahan-bahan sintesis, sehingga sering digunakan istilah detergen sintesis (3). Peraturan Gubernur Bali No 16 Tahun 2016 tentang Baku Mutu Lingkungan Hidup dan Kriteria Baku Kerusakan Lingkungan Hidup menyebutkan bahwa Baku Mutu Air Limbah Bagi Usaha dan / atau Kegiatan Domestik memiliki nilai ambang batas diantaranya untuk kandungan BOD sebesar 100 mg/ L, kandungan COD sebesar $100 \mathrm{mg} / \mathrm{L}$, kandungan TSS sebesar $100 \mathrm{mg} / \mathrm{L}$ dan rentangan $\mathrm{pH}$ air limbah sebesar 6 - 9. Hasil studi terkait nilai BOD air limbah laundry melebihi nilai ambang batas yang ditentukan dan memerlukan pengolahan air limbah.
Terdapat berbagai metode yang dapat digunakan untuk menurunkan BOD pada air limbah laundry. Salah satu cara dengan memanfaatkan metode aerasi, yaitu metode penambahan oksigen ke dalam larutan limbah untuk meningkatkan jumlah oksigen terlarut sehingga dapat memberikan suplai oksigen kepada mikroorganisme pengurai untuk menurunkan kadar zat organik yang terkandung dalam air limbah. Studi yang dilakukan oleh (4) menyatakan metode aerasi pada air limbah mempengaruhi penurunan BOD sebesar $85 \%$ dan $15 \%$ sisanya dipengaruhi oleh factor lain. . Marjono (2007) dalam (5) juga menyatakan bahwa proses aerasi selama 1 jam mengambil peran penting dalam penurunan kadar BOD air limbah domestic yaitu sebesar $56,50 \%$ dari kondisi awal air limbah. Data statistik UKM Binaan Dinas Koperasi Kota Denpasar mengenai jumlah usaha laundry yang terdapat di Desa Sidakarya, Kecamatan Denpasar Selatan menyatakan sebanyak 32 usaha laundry yang telah mendaftarkan diri. Salah satu usaha laundry yang terdapat di Desa Sidakarya yaitu Oliv Laundry Jaya 
yang berlokasi di Jalan Kebudayaan

No 1, Sidakarya Denpasar Selatan.

Usaha laundry tersebut beroperasi sejak tahun 2015 bersama dengan tiga orang karyawan. Oliv Laundry Jaya belum melakukan pengolahan terhadap limbah cair sebelum melakukan pembuangan ke badan air. Berdasarkan uraian tersebut perlu dilakukan penelitian terkait pengolahan air limbah laundry sebelum dibuang ke lingkungan dengan memanfaatkan metode aerasi. Tujuan penelitian ini adalah untuk mengetahui efektivitas perbedaan waktu aerasi terhadap penurunan kadar Biochemical Oxygen Demand (BOD) air limbah laundry. Manfaat praktis dalam penelitian ini adalah sebagai informasi dalam memanfaatkan metode aerasi untuk pengolahan air limbah dan sebagai bahan pertimbangan untuk perbaikan peningkatan kualitas air. Manfaat teoritis dalam penelitian ini adalah diharapkan menjadi refrensi dan acuan dalam pengolahan air limbah.

\section{METODE}

Penelitian ini dilakukan di Oliv Laundry Jaya, Sidakarya Denpasar Selatan. Waktu penelitian dilakukan selama Desember 2019 hingga April 2020. Jenis penelitian ini adalah Eksperimen Semu atau Quasi Eksperimen. Proses penelitian dilakukan dengan tahap pengambilan sampel di Oliv Laundry Jaya kemudian dilanjutkan dengan perlakuan eksperimen aerasi 30 menit, 60 menit dan 90 menit serta pemeriksaan sampel di Labroratorium Kimia Jurusan Kesehatan Lingkungan, Poltekkes Kemenkes Denpasar. Jumlah sampel yang dipakai sebanyak 24 sampel, dengan jumlah sampe awal sebanyak 3 buah dan jenis perlakuan sebanyak 3 varian yaitu aerasi 30 menit, 60 menit dan 90 menit.

\section{HASIL DAN PEMBAHASAN}

\section{Hasil Penelitian}

Sampe air limbah Oliv Laundry Jaya memiliki karakteristik keruh, berwarna dan berbau dengan temperature berkisar $25-30^{\circ} \mathrm{C}$. Volume rata-rata limbah yang dihasilkan adalah $1 \mathrm{~m}^{3} /$ hari. Adapun 
hasil pengukuran suhu air limbah sebelum dan sesudah aerasi yaitu :

Tabel 1.

Hasil Pengukuran Suhu Sebelum dan Sesudah Perlakuan

\begin{tabular}{|c|c|c|c|}
\hline \multirow{2}{*}{ Perlakuan } & \multirow{2}{*}{ Sampel } & \multicolumn{2}{|c|}{ Suhu $\left({ }^{\circ} \mathrm{C}\right)$} \\
\hline & & Sebelum & Sesudah \\
\hline \multirow{3}{*}{30 Menit } & $\mathrm{I}$ & 28 & 27 \\
\hline & II & 28 & 26 \\
\hline & III & 27 & 26 \\
\hline Rata - & rata & 27,6 & 26,6 \\
\hline \multirow{3}{*}{60 Menit } & $\mathrm{I}$ & 28 & 26 \\
\hline & II & 28 & 26 \\
\hline & III & 27 & 25 \\
\hline Rata - & rata & 27,6 & 25,6 \\
\hline \multirow{3}{*}{90 Menit } & I & 28 & 25 \\
\hline & II & 28 & 26 \\
\hline & III & 27 & 25 \\
\hline \multicolumn{2}{|c|}{ Rata - rata } & 27,6 & 25,3 \\
\hline \multicolumn{2}{|c|}{ Rata - rata total } & 27,6 & 25,8 \\
\hline
\end{tabular}

Tabel tersebut menunjukkan suhu rata rata air limbah sebelum aerasi sebesar $27,6^{\circ} \mathrm{C}$ dan sesudah aerasi sebesar $25,8^{\circ} \mathrm{C}$. 
Tabel 2

Hasil Pengukuran BOD Air Limbah Laundry Sebelum dan Sesudah Aerasi 30 Menit, 60 Menit dan 90 Menit

\begin{tabular}{ccccc}
\hline & \multicolumn{4}{c}{ Hasil Pengukuran (mg/ L) } \\
\cline { 2 - 5 } Sampel & $\begin{array}{c}\text { Sebelum } \\
\text { Perlakuan }\end{array}$ & $\begin{array}{c}\text { Aerasi } \\
\text { 30 Menit }\end{array}$ & $\begin{array}{c}\text { Aerasi } \\
\mathbf{6 0} \text { Menit }\end{array}$ & $\begin{array}{c}\text { Aerasi } \\
\mathbf{9 0} \text { Menit }\end{array}$ \\
\hline \multirow{2}{*}{ Sampel I } & 257 & 192 & 189 & 98 \\
& 257 & 200 & 182 & 101 \\
Sampel II & 357 & 292 & 189 & 107 \\
& 357 & 278 & 170 & 106 \\
Sampel III & 189 & 167 & 131 & 85 \\
& 189 & 165 & 129 & 87 \\
\hline Rata-Rata & 267,7 & 215,7 & 165 & 97,3 \\
\hline
\end{tabular}

Hasil pengukuran pada table 2 menunjukkan nilai BOD awal air limbah laundry rata-rata sebesar 267,7 mg/L. Perlakuan 30 menit menurunkan nilai BOD hingga nilai rata-rata sebesar $215,7 \mathrm{mg} / \mathrm{L}$, perlakuan 60 menit menurunkan nilai BOD hingga nilai rata-rata 165 mg/L. Sedangkan pada perlakuan 90 menit penurunan nilai BOD mencapai rata-rata $97,3 \mathrm{mg} / \mathrm{L}$.
Melihat angka BOD setelah melalui tahap aerasi, variansi waktu yang memenuhi persyaratan dalam menurunkan nilai BOD yaitu aerasi 90 menit dengan nilai BOD sebesar 97,3 mg/L sesuai dengan Pergub Bali No. 16 Tahun 2016 tentang Baku Mutu Lingkungan Hidup dan Baku Kerusakan Lingkungan Hidup kadar BOD maksimal sebesar $100 \mathrm{mg} / \mathrm{L}$ 
Tabel 3

Hasil Efektivitas Penurunan BOD Sebelum dan Setelah Perlakuan Aerasi 30 Menit, 60 Menit dan 90 Menit

\begin{tabular}{|c|c|c|c|c|c|}
\hline Perlakuan & Sampel & Replikasi & $\begin{array}{c}\text { Hasil } \\
\text { Sebelum } \\
\text { Perlakuan } \\
(\mathrm{mg} / \mathrm{L})\end{array}$ & $\begin{array}{c}\text { Hasil } \\
\text { Sesudah } \\
\text { Perlakuan } \\
(\mathrm{mg} / \mathrm{L})\end{array}$ & Efektivitas (\%) \\
\hline
\end{tabular}

\begin{tabular}{cccccc}
\hline \multirow{5}{*}{ 30 Menit } & I & 1 & 257 & 192 & 25 \\
& I & 2 & 257 & 200 & 22 \\
& II & 3 & 357 & 292 & 18 \\
& II & 4 & 357 & 278 & 22 \\
& III & 5 & 189 & 167 & 12 \\
& III & 6 & 189 & 165 & 13 \\
\hline \multirow{5}{*}{ 60 menit } & Rata-Rata & & 267,7 & 215,7 & 19 \\
& I & 1 & 257 & 189 & 26 \\
& I & 2 & 257 & 182 & 29 \\
& II & 3 & 357 & 189 & 47 \\
& II & 4 & 357 & 170 & 52 \\
& III & 5 & 189 & 131 & 31 \\
\hline \multirow{5}{*}{ 90 Menit } & III & 6 & 189 & 129 & 32 \\
& Rata-Rata & & 267,7 & 165 & 36 \\
\hline & I & 1 & 257 & 98 & 62 \\
& I & 2 & 257 & 101 & 61 \\
& II & 3 & 357 & 107 & 70 \\
& II & 4 & 357 & 106 & 70 \\
& III & 5 & 189 & 85 & 55 \\
\hline & III & 6 & 189 & 87 & 54 \\
\hline
\end{tabular}

Hasil pengukuran nilai BOD pada table 3 menunjukkan presentase yang berbeda pada tiap perlakuan. Perlakuan aerasi selama 30 menit memiliki nilai efektivitas sebesar $19 \%$ dengan angka penurunan sebesar $52 \mathrm{mg} / \mathrm{L}$. perlakuan aerasi 60

\section{Pembahasan Penelitian}

\section{Suhu Air Limbah}

Tinggi rendahnya suhu air limbah memiliki peran yang penting dalam mempengaruhi kualitas air limbah menit memiliki nilai efektivitas sebesar $36 \%$ dengan angka penurunan sebesar 102,7 $\mathrm{mg} / \mathrm{L}$. Perlakuan aerasi selama 90 menit memiliki nilai efektivitas sebesar $62 \%$ dengan angka penurunan sebesar $170,4 \mathrm{mg} / \mathrm{L}$.

sehingga pengukuran suhu perlu dilakukan sebelum pengolahan menggunakan aerasi. Hasil pengukuran suhu menunjukkan suhu 
rata-rata sampel awal sebelum perlakuan sebesar $27,6{ }^{\circ} \mathrm{C}$ dan suhu sesudah perlakuan memiliki rata-rata $25,8{ }^{\circ} \mathrm{C}$. Suhu memiliki pengaruh terhadap keberhasilan pengolahan air limbah, sehingga apabila melebihi ambang batas yang ditentukan perlu adanya pengendalian sebelum tahap pengolahan berlangsung (6). Peraturan Gubernur Bali No. 16 Tahun 2016 tentang Baku Mutu Lingkungan Hidup dan Kriteria Baku Kerusakan Lingkungan Hidup menyatakan suhu air limbah yang dibuang ke badan air maksimal pada temperature $38^{\circ} \mathrm{C}$, sehingga suhu sampel air limbah telah memenuhi persyaratan untuk dilanjutkan pada proses aerasi.

\section{BOD Air Limbah Laundry}

Hasil pemeriksaan BOD air limbah laundry sebelum perlakuan menunjukkan angka rata-rata sebesar 267,7 mg/L. Sesudah diberikan perlakuan sampel mengalami penurunan, pada aerasi 30 menit BOD air limbah laundry memiliki rata-rata $215,7 \mathrm{mg} / \mathrm{L}$, perlakuan aerasi 60 menit dengan rata-rata kandungan BOD 165 $\mathrm{mg} / \mathrm{L}$ dan perlakuan aerasi 90 menit dengan kandungan BOD
97,3 mg/L. Hasil pemeriksaan tersebut menunjukkan adanya penurunan BOD air limbah laundry sebelum dan sesudah diberikan perlakuan aerasi.

Penurunan BOD air limbah laundry disebabkan oleh adanya pemasukan oksigen ke dalam air limbah, yang membantu dalam meregenerasi zat- zat organic dalam air limbah laundry. Kandungan BOD air limbah laundry pada perlakuan aerasi 30 menit dan 60 menit belum memenuhi syarat baku mutu, sedangkan perlakuan 90 menit aerasi telah sesuai dengan persyaratan baku mutu air limbah. Berdasarkan hasil tersebut terlihat bahwa lama waktu aerasi berbanding lurus dengan penurunan kandungan BOD air limbah laundry. Suplay oksigen yang semakin meningkat menyokong pertumbuhan populasi organisme baik sehingga proses penguraian air limbah semakin cepat (4). Proses dekomposisi bahan organic oleh mikroorganisme dapat menurunkan oksigen terlarut yang berperan dalam penurunan bahan organic 
dalam air limbah. Semakin tinggi bahan organic dalam air limbah semakin banyak pula oksigen yang dibutuhkan oleh mikroorganisme sehingga menyebabkan penurunan oksigen terlarut. Dalam hal tersebut aerasi memiliki peran yang besar dalam memenuhi kebutuhan oksigen air limbah (7).

\section{Efektivitas Metode Aerasi}

Aerasi merupakan istilah lain dari tranfer gas, lebih dikhususkan pada transfer gas oksigen atau proses penambahan oksigen ke dalam air. Keberhasilan proses aerasi dalam menurunkan kadar cemaran air limbah tergantung pada besarnya nilai suhu, kejenuhan oksigen, karateristik air dan turbulensi air. Suhu air limbah yang melebihi ambang batas yang ditetapkan dapat mempengaruhi karakteristik air limbah sehingga perlu adanya keseimbangan kondisi air limbah sebelum diberikan perlakuan (8) Dalam penelitian ini, penulis memanfaatkan aerator jenis RB 600 dengan suplay oksigen sebesar 2,5 liter/ menit. Pada tiap perlakuan sampel mendapat suplay oksigen sebesar 5 liter/ menit per 1 liter larutan sampel. Aerasi bertujuan untuk mengurangi atau menghilangkan polutan dengan memanfaatkan aktivitas mikroorganisme dalam perairan. Menurut (9) terdapat beberapa poin yang mencakup dasar perencanaan aerasi yaitu : kekuatan pengadukan aerator berkisar 20-30 W/m³ peralatan yang digunakan meliputi submersible aerator, immersible aerator, surface aerator, blower atau diffuser; dan aerator yang digunakan berjumlah dua atau lebih. Perlakuan aerasi pada penelitian ini mengambil dua poin dasar pelaksanaan aerasi yaitu jumlah aerator dan jenis aerator yang digunakan yaitu bubble aerator/ diffuser aerator. Penelitian ini memanfaatkan aerator tipe RB600 sebanyak dua buah pada tiap perlakuan aerasi dengan kekuatan pengadukan sebesar 5W/L, jika dikonversi sesuai dasar perencaraan menjadi $0,005 \mathrm{~W} / \mathrm{m}^{3}$. Aerator RB 600 tergolong kedalam jenis bubble aerator atau aerator dengan gelembung difuser, yang merupakan proses aerasi dengan menyemprotkan atau menginjeksikan udara melalui dasar dari bak air yang akan diaerasi atau 
melalui penempatan nozzle pada dasar bak aerasi. Pemilihan aerator RB-600 didasari oleh konsep pemanfaatkan gelembung udara dalam proses supply oksigen serta secara tidak langsung dapat membantu homogenitas sampel saat perlakuan aerasi. Pergerakan gelembung udara yang berasal dari aerator mengakibatkan air limbah dapat kontak dengan udara sekitar, sehingga proses transfer oksigen dapat berjalan maksimal (10). Bubble aerator atau diffuser aerator tergolong dalam high rate aeration yaitu aerasi yang berlangsung dengan kecepatan tinggi. Perlakuan high rate aeration memerlukan waktu yang lebih singkat jika dibandingkan dengan extended aeration. Hal tersebut menjadi salah satu faktor penggunaan metode aerasi dengan kecepatan tinggi (11). Hasil pemeriksaan BOD air limbah laundry yang berasal dari Oliv Laundry Jaya menunjukkan nilai efektivitas yang berbeda pada perlakuan 30 menit, 60 menit dan 90 menit. Nilai efektivitas penurunan BOD air limbah laundry berbanding lurus dengan lama waktu aerasi. Waktu perlakuan aerasi 90 menit memiliki kemampuan tertinggi dalam menurunkan BOD air limbah laundry sebesar 170,4 mg/L dengan efektivitas sebesar $62 \%$ sedangkan yang paling rendah adalah waktu aerasi selama 30 menit dengan penurunan sebesar $52,7 \mathrm{mg} / \mathrm{L}$ dengan efektivitas 19\%. Hasil uji ANOVA menunjukkan nilai Sig. 0,000 yang artinya $\mathrm{H} 0$ ditolak dan Ha diterima karena nilai Probabillitas $<0,05$. Hal tersebut menunjukkan ada perbedaan yang bermakna dalam penurunan BOD air limbah setelah diberikan perlakuan aerasi 30 menit, 60 menit dan 90 menit. Waktu aerasi yang optimal dalam menurunkan BOD air limbah laundry dalam penelitian ini adalah 90 menit. Hal tersebut dikarenakan dalam waktu 90 menit aerasi pada supply udara 5 liter/ menit telah menurunkan BOD air limbah laundry hingga 97,3 mg/L dengan tingkat efektivitas sebesar $62 \%$ sesuai dengan Peratuan Gubernur Bali No. 16 tahun 2016 tentang Baku Mutu Lingkungan Hidup dan Kriteria Baku Kerusakan Lingkungan Hidup yaitu kandungan BOD air limbah untuk kegiatan atau 
usaha domestic sebesar $100 \mathrm{mg} / \mathrm{L}$.

\section{SIMPULAN DAN SARAN}

Berdasarkan hasil penelitian yang telah dilakukan, dapat ditarik kesimpulan sebagai berikut :

1) Kandungan BOD air limbah laundry sebelum perlakuan aerasi memiliki nilai rata-rata sebesar : 267,7 mg/L 2) Ratarata kandungan BOD air limbah laundry setelah diberi perlakuan aerasi selama 30 menit kadar BOD nya menjadi $215,7 \mathrm{mg} / \mathrm{L}$ dengan tingkat efektivitas sebesar $19 \%$, perlakuan aerasi 60 menit kadar BOD nya menjadi $165 \mathrm{mg} / \mathrm{L}$ dengan tingkat efektivitas sebesar $36 \%$ dan perlakuan aerasi 90 menit kadar BOD menjadi 97,3 mg/L dengan tingkat efektivitas sebesar $62 \%$. 3) Perlakuan metode aerasi untuk menurunkan kandungan BOD air limbah laundry memiliki perbedaan yang signifikan. Waktu aerasi selama 90 menit dikatakan paling efektif dalam menurunkan BOD air limbah laundry menjadi $97,3 \mathrm{mg} / \mathrm{L}$ sesuai dengan Peraturan
Gubernur Bali No. 16 Tahun 2016 tentang Baku Mutu Lingkungan Hidup dan Kriteria Baku Kerusakan Lingkungan Hidup kandungan BOD yang diperbolehkan sebesar 100 mg/L. Adapun saran yang dapat disampaikan yaitu :

1) Diharapkan melakukan pengolahan limbah laundry sebelum membuang limbah ke lingkungan. Pengolahan dapat dilakukan dengan melakukan pengendapan air limbah kemudian melakukan aerasi dengan laju transfer udara sebesar $50 \mathrm{~L} /$ menit atau laju aerasi $50 \mathrm{~W} / \mathrm{m}^{3}$ untuk $1 \mathrm{~m}^{3}$ air limbah selama 90 menit. 2) Dalam proses aerasi sebaiknya memastikan nozzle atau lubang udara berada di dasar bak aerasi untuk memaksimalkan air limbah kontak dengan udara, sehingga dapat membantu penuru nan kandungan BOD air limbah laundry. 3) Diharapkan dapat melakukan penelitian terkait penurunan BOD menggunakan jenis aerator yang berbeda dan skala yang lebih besar, 
sehingga jika digunakan pada pengolahan air limbah laundry hasilnya lebih efektif. 4)Pada penelitian selanjutnya diharapkan dilakukan pemeriksaan parameter air limbah secara lengkap, untuk melihat pengaruh perlakuan terhadap parameter lainnya.

\section{DAFTAR PUSTAKA}

1. I Gede Herry Purnama SGP.

Pengolahan Air Limbah

Binatu ( Laundry ) Dengan

Menggunakan Metode Lahan

Basah Buatan ( Horizontal

Sub Surface Flow Constructed

Wetlands ). 2015;(November).

2. Rosariawari F. Penurunan

konsentrasi limbah deterjen

menggunakan Furnace Bottom

Ash (FBA). Rekayasa Perenc. 2008;4(3).

3. Apriyani N. Penurunan Kadar Surfaktan dan Sulfat dalam Limbah Laundry. Media Ilm

Tek Lingkung. 2017;2(1):3744.

4. Arsawan M, Budiarsa Suyasa

I, Suarna W. Pemanfaatan

Metode Aerasi Dalam
Pengolahan Limbah

Berminyak. Ecotrophic J

Environ Sci. 2012;2(2):1-9.

5. Mobarokah I. Gabungan

Metode Aerasi dan Adsorpsi

dalam Menurunkan Fenol dan

COD pada Limbah Cair UKM

Batik Purnama. 2010;

6. Ratnawati E. Pengaruh Waktu Reaksi dan Suhu Pada Proses Ozonasi Terhadap Penurunan Warna, COD dan BOD Air Limbah Industri Tekstil. J Kim dan Kemasan. 2011;33(1):107.

7. Hidayah EN, Djalalembah A, Asmar GA, Cahyonugroho $\mathrm{OH}$. Pengaruh Aerasi Dalam Constructed Wetland Pada Pengolahan Air Limbah Domestik. J Ilmu Lingkung. 2018;16(2):155.

8. Abuzar SS, Putra YD, Emargi RE. k o efis i en transfe r gas (kla) pada prose s aerasi menggunaka n tray aerator bertin gkat 5 ( 1 i ma) gas tra nsfer coefficient (kla ) in aeration process using 5 ( five)storey t 
ra y a e r a tor.

2012;9(2):155-63.

9. Siregar S. Instalasi

Pengolahan Air Limbah.

Yogyakarta: Kanisus;

10. Hartini E. Jurnal Kesehatan

Masyarakat J-Kesmas Jurnal
Kesehatan Masyarakat.

2018;4(1):43-7.

11. Ningtyas R. Pengolahan Air

Limbah Domestik Dengan

Proses Lumpur Aktif.

2010;3(2):160-74. 